\title{
Cold storage of budsticks/clefts for staggered grafting in persimmon trees
}

\author{
Armazenamento refrigerado de ramos porta-borbulhas/garfos \\ para enxertia escalonada em caquizeiro
}

\author{
Pedro Maranha Peche ${ }^{\mathrm{I}}$ Alana Lauar Figueiredo ${ }^{\mathrm{I}}$ Rafael Pio ${ }^{\mathrm{II}}$ Cínthia Aparecida Andrade ${ }^{\mathrm{III}}$ \\ Evaldo Tadeu de Melo ${ }^{I}$ Caio Morais de Alcântara Barbosa ${ }^{\mathrm{I}}$
}

\section{ABSTRACT}

The persimmon tree is propagated by grafting and the rootstocks are produced from seeds. Grafting is done in July, which coincides with the time when the persimmon trees are pruned. But, at this time, many rootstocks are not yet eligible to receive the grafts. In this case budsticks/cleft storage is an option. Thus, this study aimed to verify the feasibility of cold storage of budsticks/cleft and verify the grafting method to promote better graft development. Rootstock was sown in August 2012 and the branches were collected in July 2013. Part of the branches was used for grafting (budding and cleft graft methods) in one-year old rootstocks and the other part was stored at low temperature (cuttings wrapped in moistened paper and then wrapped in polyethylene bags placed in cold storage at $4^{\circ} \mathrm{C}$ ), during the months of August to December. Every 30 days, a number of branches was removed from the cold storage to perform grafting by budding and cleft and to quantify total sugars and starch in the budsticks/cleft stored. One hundred and twenty days after the grafting was performed, the length and diameter of the bud, number of leaves, sprouting percentage, dry weight of aerial part and root from the grafts were measured. It was concluded that there is no difference in the budding graft for different periods, but in seedlings grafted by the cleft grafting method there is greater growth when the clefts have been in cold storage for 60 to 120 days.

Key words: Diospyrus kaki, seedlings production, cleft graft, budding.

\section{RESUMO}

O caquizeiro é propagado por enxertia e os portaenxertos são produzidos por sementes. A enxertia é realizada em julho, que coincide com a época de poda dos caquizeiros. Porém, nessa época, muitos porta-enxertos ainda não estão aptos a receberem os enxertos. Nesse sentido, o armazenamento dos ramos porta-borbulhas/garfos seria uma opção. Assim, o presente trabalho teve por objetivo de verificar a viabilidade do armazenamento refrigerado dos ramos porta-borbulhas/garfos e diagnosticar o método de enxertia para promover melhor desenvolvimento do enxerto. A semeadura dos porta-enxertos foi realizada em agosto de 2012 e os ramos foram coletados em julho de 2013. Uma parte dos ramos foi utilizada para a realização da enxertia (métodos de borbulhia e garfagem) em porta-enxertos de um ano de idade e a outra parte foi armazenada sob baixa temperatura (estacas envoltas em papel umedecido, embrulhadas em sacos de polietileno colocadas em câmara fria $a 4^{\circ} \mathrm{C}$ ), pelos meses de agosto a dezembro. A cada 30 dias, uma quantidade de ramos foi removida da câmara fria para a realização das enxertias por borbulhia e garfagem e para a quantificação dos açúcares totais e amido dos ramos porta-borbulhas/garfos armazenados. Passados 120 dias da realização das enxertias, foram mensurados o comprimento e diâmetro do broto, número de folhas, porcentagem de brotação, massa seca da parte aérea e das raizes dos enxertos. Concluise que não há diferença na brotação dos enxertos para as diferentes épocas, porém, em mudas enxertadas pelo método de garfagem, há maior crescimento quando os garfos são armazenados a frio durante 60 a 120 dias.

Palavras-chave: Diospyrus kaki, produção de mudas, garfagem, borbulhia.

\section{INTRODUCTION}

The persimmon tree (Diospyros kaki L.) is a fruit bearing tree from Asia, traditionally cultivated in temperate or subtropical climates (MARTINELI

\footnotetext{
'Programa de Pós-graduação em Fitotecnia, Departamento de Agricultura, Universidade Federal de Lavras (UFLA), Lavras, MG, Brasil. "Departamento de Agricultura, Universidade Federal de Lavras (UFLA), 37200-000, Lavras, MG, Brasil. E-mail: rafaelpio@dag.ufla.br. Correspondig author.

IIIPrograma de Pós-graduação em Fisiologia Vegetal, Departamento de Biologia, Universidade Federal de Lavras (UFLA), Lavras, MG, Brasil. 
et al., 2013). The Brazilian persimmon production has grown in recent years, since it is very profitable. The State of São Paulo, with over 8,100ha under production, has the largest cultivated area (ALVES et al., 2011).

The traditional method to produce persimmon tree seedlings is by grafting, performed in Diospyros kaki plants, or in American persimmons D. lotus and D. virginiana (KOCHANOVA et al., 2012; FERRI et al., 2013;). In Brazil, due to the lack of seedling programs using American persimmons, or also the existence of a persimmon that could potentially be used as rootstock, the only alternative is to extract seeds from the commercial cultivars themselves to form the rootstocks. This is inconvenient because they do not all have seeds, and when they do, they are scarce, besides their have low germination and lack of uniform rootstock growth (BUENO et al., 2014). An option for the persimmon tree would be to form seedlings using the cuttings method, but the rate of rooting from cuttings is low (BASTOS et al., 2005).

The alternative would be the storage of budsticks/clefts, in order to maximize the use of the branches fragmented during pruning and maximizing the greater use of rootstocks produced due to the lack of uniformity of the rootsticks in the nursery (PIO et al., 2007). Storage at a low temperature, a technique whose purpose it is to keep the propagation material away from light, or else to supply the need for cold, aims to overcome the endodormancy of buds (BIASI, 1996; BASTOS et al., 2009). In citrus, the storage of budsticks/clefts at low temperature has already been studied and proved to be a feasible technique (MACIEL et al., 2008). In the case of the quince tree, CELANT et al. (2010) reported that the budsticks/clefts must be stored for only 30 days, and grafting by clefts promoted greater growth of the grafts, compared to grafting by budding. Hence, the purpose of the present study was to look at the feasibility of cold storage of the budsticks/cleft persimmon branches and to diagnose the grafting method that best promotes graft development.

\section{MATERIALS AND METHODS}

The experiment was performed at the Center for Seedling Production of São Bento do Sapucaí-SP, belonging to the Coordenadoria de Assistência Técnica Integral (CATI), located in the Mantiqueira mountains at a latitude of $22^{\circ} 41^{\prime}$ (S), longitude of $45^{\circ} 43^{\prime}(\mathrm{W})$, altitude of 886 meters and mesothermal climate (Cwa).

Seeds of mature fruit of the 'Pomelo' persimmon tree were extracted in February 2012. After washing and drying the seeds were placed in a plastic bag and stored in a cold storage at a temperature of $4^{\circ} \mathrm{C}$. In August, the seeds were buried two centimeters deep in a sand bed, which was moistened daily. After 60 days the seedlings were transplanted into plastic bags with a $2.5 \mathrm{~L}$ capacity filled with a substrate of pinus bark, burnt rice husks, and organic matter from the composting of plant residues. Rootstocks were kept in a nursery made of a shading screen $(50 \%$ luminosity) and daily irrigation was performed with watering cans.

In July 2013, a random sample of 200 rootstocks in a lot of 2,000 rootstocks was measured for height and diameter at the graft site, $15 \mathrm{~cm}$ above soil level. The classes of diameters were separated into $0-4.9 \mathrm{~mm}, 5-6.7 \mathrm{~mm}, 6.8-8.5 \mathrm{~mm}$ and were ready for grafting (greater than $8.6 \mathrm{~mm}$ ) according to the recommendations of BUENO et al. (2014); classes of rootstock height were separated into $0-35.3 \mathrm{~cm}$, $35.4-53.7 \mathrm{~cm}, 53.8-72 \mathrm{~cm}$ and above $72.1 \mathrm{~cm}$.

Branches of the 'Guiombo' persimmon tree collected in July 2013 together with the pruning were standardized with a $20 \mathrm{~cm}$ length. Part of the branches was grafted immediately, in July, at a height of 10 to $15 \mathrm{~cm}$ above the soil level. The grafting methods used were: plate type budding, in which the buds were tied with transparent plastic tape, and after 30 days these tapes were removed and then the aerial part of the rootstock, above the graft was decapitated; and a double slit type cleft graft, and cleft with three buds approximately six centimeters long, and grafts were tied with plastic tape and protected for 30 days with transparent plastic bags $(15 \mathrm{~cm}$ long and $3 \mathrm{~cm}$ in diameter) in order to form a moist chamber and avoid dessication of the propagative material.

Another part of the branches was placed in cold storage. For storage the cuttings were wrapped in moistened paper, immersed in fungicide (Captan 500PM, at a concentration of $10 \mathrm{~g} \mathrm{~L}^{-1}$ ) for three minutes, then wrapped in polyethylene bags and placed in cold storage at a temperature of $4^{\circ} \mathrm{C}$, maintained from August to December. Every 30 days, a certain number of branches weres removed from cold storage to perform grafting using both methods (budding and cleft grafting) in rootstocks that had a diameter greater than $8.6 \mathrm{~mm}, 15 \mathrm{~cm}$ above the soil level, and higher than $72.1 \mathrm{~cm}$. The design 
used was entirely randomized, with a factorial of 6x2 (first factor: grafting season; second factor; type of graft), with four repetitions and 10 grafts per plot, with a total of 480 grafts.

Total soluble sugars and starch of the budsticks/cleft stored were quantified and also the control which did not undergo the storage process. In order to extract the total soluble sugars, 0.2 of dry mass of the branches and rootstocks were used, homogenized in $5 \mathrm{~mL}$ of phosphate buffer $0.1 \mathrm{M} \mathrm{pH} 7.0$, followed by a water bath for $30 \mathrm{~min}$ at $40^{\circ} \mathrm{C}$ and later centrifuged at $10,000 \mathrm{rpm}$ for 20min; the supernatant was collected and stored in black plastic pots at $-20^{\circ} \mathrm{C}$. To extract the starch, the pellet resulting from the extraction of total soluble sugars was resuspended with $8 \mathrm{~mL}$ of potassium acetate buffer $200 \mathrm{mM} \mathrm{pH} 4.8$ and $2 \mathrm{~mL}$ of amyloglucosidase enzyme solution $\left(1 \mathrm{mg} \mathrm{mL} \mathrm{mL}^{-1}\right)$ were added and incubated at $40^{\circ} \mathrm{C}$ for two hours and then later centrifuged at $10.000 \mathrm{rpm}$ for $20 \mathrm{~min}$; the resulting supernatant was collected and discarded and the pellet volume was completed to reach $15 \mathrm{~mL}$ with distilled water. Starch and total soluble sugars were quantified using the anthrone method (ZANANDREA et al., 2009).

Grafts were conducted on a single stem and periodical debudding was performed. One hundred and twenty days after the graft was performed for each period, percentage of graft sprouting, length and diameter of the sprout, number of leaves, dry mass of the aerial part and roots were measured. Dry masses were obtained by drying the plant material in a forced air circulation oven at $65^{\circ} \mathrm{C}$, for $72 \mathrm{~h}$ and later weighed on a semi-analytic balance. Data were submitted to analysis of variance and the means were grouped by the Scott-Knott test with a $5 \%$ probability level.

\section{RESULTS AND DISCUSSION}

Evaluating the rootstock of the 'Pomelo' persimmon tree before the grafting was done, it was reported that only $57 \%$ of them were suitable for grafting, in other words, had a diameter greater than $8.6 \mathrm{~mm} 15 \mathrm{~cm}$ above the soil level and a height of more than $72.1 \mathrm{~cm}$, according to the indications of BUENO et al. (2014) (Figure 1). These results supported the statement by BUENO et al. (2014), concerning the lack of uniformity of the persimmon tree rootstock. In this sense, storage of the budsticks/cleft branches would be the feasible alternative, agreeing with the statement by MACIEL et al. (2008) who emphasize that the storage of budsticks/cleft branches allows a synchrony between the maturing of the branches and the moment when the rootstocks are ready for the graft to be performed.

According to the statistical analysis of the quantifications performed after grafting, interaction occurred only between the factors to carry out the grafting. As to the isolated factors, there was a statistical difference between the grafting periods and the type of graft for the variables number of leaves, dry matter of the aerial part and roots.

Although there was no statistical difference in the percentage of sprouting grafts, it is reported that the índices were above $80 \%$ (Table 1 ). Percentage of sprouting reflects the success of the tissue regeneration in the graft and rootstock region (CELANT et al., 2010). Through these results it is reported that it is possible to store the budstocks/ cleft branches of the 'Guiombo' persimmon tree for up to 150 days. These results are promising from the point of view of optimization and the better use of rootstocks in the seedling production system for this fruit tree, since, according to the results shown in figure $1,57 \%$ of the roostocks were suitable for grafting in the traditional period for carrying out this procedure.

Thus, since it is feasible to store the budstick/cleft branches, the other rootstocks which were not suitable for grafting can be used later. It should be underscored that not all lignous and deciduous fruit trees can be used for the storage of budsticks/cleft branches, since, according to CELANT et al. (2010), the budsticks/cleft branches of quince trees can be stored for up to 30 days. According to the authors, at the end of 60 days, it was seen that calluses were formed and rhizogenic initiation occurred on the budsticks/cleft branches of quince trees. Since the persimmon tree branches have a low rhizogenic potential (BASTOS et al., 2005), this may be a reason for the succcessful storage of the budsticks/cleft branches at a low temperature, since the reserves are not exausted because of the rhizogenic initiation.

As to the period when grafting is performed, only in branches that were stored up to the month of December, they had the grafts with the smallest number of leaves (Table 1). In the case of the dry mass of the aerial part of grafts, ie, the sprouts, grafts performed between July and August, ie, on budsticks/cleft branches that did not undergo the storage process or that were kept for 30 days in cold storage presented the highest values (Table 1). Usually, deciduous lignous species, such as fruit trees 


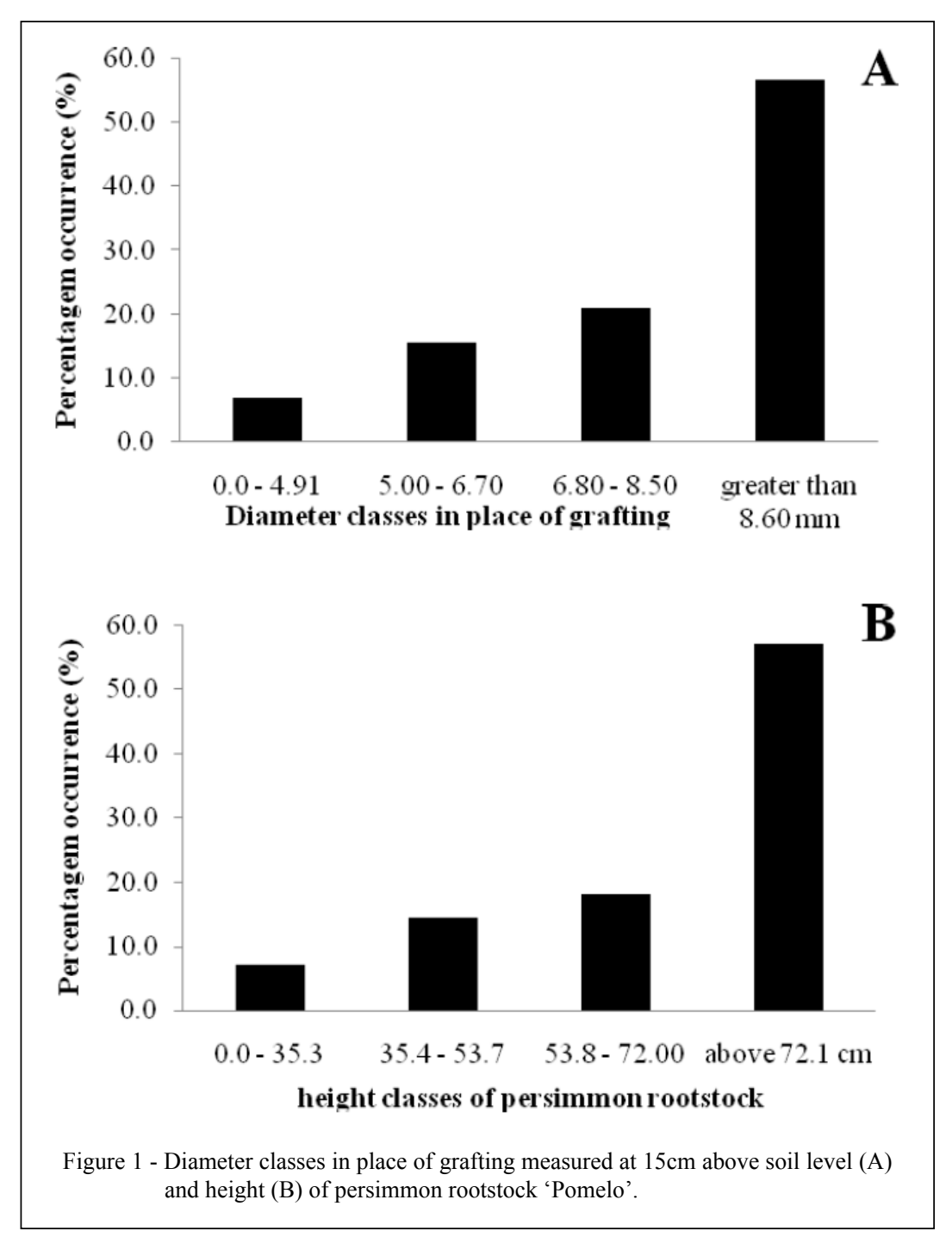

from temperate climates present high development indices when the grafts are performed during a period of vegetative rest (CELANT et al., 2010).

As to the methods, cleft grafting helped to increase the number of leaves and masses of the aerial part (graft buds) and roots (Table 1). These differences regarding the grafting methods are related to the seedling, since the clefts have a greater amount of reserves (carbohydrates) than the buds, which helps the graft healing and sprouting (BIASI, 1996). SEIFERT et al. (2009) also reported a higher percentage of sprouts in dry mass of sprouting in pear trees grafted by clefting, compared to the grafts performed by budding in quince tree rootstocks.
In the case of length of grafts, there was no difference between the methods for grafting in budsticks/cleft branches that had not been stored and those that remained 30 days in cold storage (until August). However, for branches that were stored between the months of September and December, cleft grafting promoted a greater length of grafts (Table 2). In figure 2A, it is reported that there was a linear increase in the total soluble sugar contents insofar as the branches remained stored over time. CORSATO et al. (2008) reported increased total soluble sugar contents in persimmon tree branches beginning at the end of the dormancy period. Since the persimmon tree branches used in this study were collected precisely during the dormancy period, a 
Table 1 - Percentage of graft sprouting (PS), diameter of the sprout (DS), number of leaves (NL), dry masse of the aerial part (DMAP) and root (DMR) of persimmon grafted by grafting and budding at different times.

\begin{tabular}{|c|c|c|c|c|c|}
\hline & PS $(\%)^{(1)}$ & $\mathrm{DS}(\mathrm{mm})^{(1)}$ & $\mathrm{NL}^{(1)}$ & $\operatorname{DMAP}(\mathrm{g})^{(1)}$ & $\operatorname{DRM}(g)^{(1)}$ \\
\hline Grafting & $87.50^{\mathrm{ns}}$ & $6.50^{\mathrm{ns}}$ & $20.06 \mathrm{a}$ & $18.55 \mathrm{a}$ & $16.13 \mathrm{a}$ \\
\hline Budding & 89.58 & 5.98 & $16.37 \mathrm{~b}$ & $15.67 \mathrm{~b}$ & $15.30 \mathrm{~b}$ \\
\hline & & Grafted at di & mes------- & 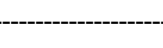 & \\
\hline July & $87.50^{\mathrm{ns}}$ & $6.38^{\mathrm{ns}}$ & $19.46 \mathrm{a}$ & $22.12 \mathrm{a}$ & $15.51 \mathrm{~b}$ \\
\hline August & 91.25 & 6.83 & $18.45 \mathrm{a}$ & $19.12 \mathrm{a}$ & $16.51 \mathrm{~b}$ \\
\hline September & 88.75 & 6.16 & $17.92 \mathrm{a}$ & $16.25 \mathrm{~b}$ & $16.05 \mathrm{~b}$ \\
\hline October & 80.00 & 5.47 & $19.26 \mathrm{a}$ & $13.64 \mathrm{~b}$ & $13.49 \mathrm{~b}$ \\
\hline November & 96.25 & 6.78 & $19.19 \mathrm{a}$ & $14.97 \mathrm{~b}$ & $13.37 \mathrm{~b}$ \\
\hline December & 87.50 & 5.80 & $15.91 \mathrm{~b}$ & $16.56 \mathrm{~b}$ & $19.38 \mathrm{a}$ \\
\hline C.V. (\%) & 10.89 & 16.80 & 14.87 & 17.45 & 21.07 \\
\hline
\end{tabular}

${ }^{(1)}$ Means followed by the same letter in the column do not differ by the Scott-Knott test $(\mathrm{P} \leq 0.05)$. ns - not significant.

rise in the total soluble sugar contents was expected. Conversely, there was a reduction in the starch contents beginning with the $12^{\text {th }}$ day of storage up to 60 days, which is explained by the conversion to soluble sugar. However, starch content increased later after 72 days, possibly due to preventing the sprouting of buds of the stored branches, to detriment of the low temperature of the cold conservation storage (Figure 2B). CORSATO et al. (2008) also observed an equation identical to that of the present paper for starch contents in persimmon tree branches over time.

Comparing the storage periods in each grafting method it is noted that there was no difference between the periods when grafting was done by clefting (Table 2). However, the budsticks/ cleft branches that were not stored, or that remained in cold storage until the month of August, when they were grafted by budding presented a longer graft. The same results were observed by CELANT et al. (2010) in quince trees, which showed that cleft grafting promotes a greater length of grafts, even when they are kept in cold storage. SEIFERT et al. (2009) also observed a greater length of the pear tree grafts performed by clefting and comparison with those performed by budding.

\section{CONCLUSION}

Budsticks/cleft branch storage is an efficient method to stagger and/or produce persimmon tree seedlings out of season. The clefting method provides greater graft growth when the clefts are submitted to cold storage for 60 to 120 days.

Table 2 - Length of the grafts derived from persimmon branches grafted by grafting and budding at different times.

\begin{tabular}{|c|c|c|}
\hline Grafted at different times & Grafting & Budding \\
\hline & \multicolumn{2}{|c|}{ - } \\
\hline July & $60.85 \mathrm{Aa}$ & $62.82 \mathrm{Aa}$ \\
\hline August & $53.83 \mathrm{Aa}$ & $52.99 \mathrm{Aa}$ \\
\hline September & $57.70 \mathrm{Aa}$ & $38.68 \mathrm{Bb}$ \\
\hline October & $54.61 \mathrm{Aa}$ & $41.48 \mathrm{Bb}$ \\
\hline November & $49.24 \mathrm{Aa}$ & $44.11 \mathrm{Bb}$ \\
\hline December & $51.70 \mathrm{Aa}$ & $26.88 \mathrm{Bc}$ \\
\hline
\end{tabular}

${ }^{(1)}$ Means followed by the same letter capitalized on the line and lowercase in the column do not differ by the Scott-Knott test $(\mathrm{P} \leq 0.05)$.

Ciência Rural, v.46, n.8, ago, 2016. 

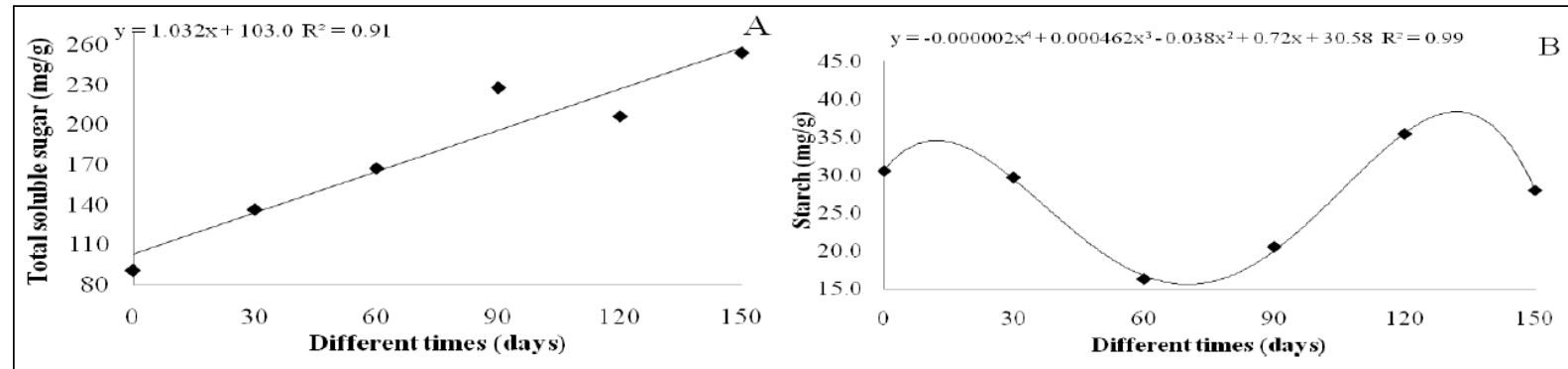

Figure 2 - Total soluble sugar ( $\mathrm{mg} / \mathrm{g})(\mathrm{A})$ and starch ( $\mathrm{mg} / \mathrm{g})(\mathrm{B})$ in branches 'Guiombo' persimmon storage in a cold chamber at $4^{\circ} \mathrm{C}$ for different times.

\section{REFERENCES}

ALVES, G. et al. First report of Pestalotiopsis diospyri causing canker on persimmon trees. Revista Brasileira de Fruticultura, v.33, n.3, p.1019-1022, Sept. 2011. Available from: $<$ http://www.scielo.br/scielo.php?script=sci_arttext\&pid $=$ S0100-29452011000300039 $>$. Accessed: May 06, 2015. doi: 10.1590/S0100-29452011005000103.

BASTOS, D.C. et al. Effect of indolebutyric acid, etiolation and basal injury on propagation of star fruit by hardwood cuttings. Ciência e Agrotecnologia, v.33, n.1, p.313-318, Jan./Feb. 2009. Available from: <http://www.scielo.br/scielo.php?script $=$ sci arttext\&pid=S1413-70542009000100043\&lng=pt\&nrm= iso\&tlng=pt $>$. Accessed: May 06, 2015. doi: 10.1590/S141370542009000100043.

BASTOS, D.C. et al. Rooting of hardwood and herbaceous cuttings of japanese persimmon tree cultivars treated with different concentration of indolbutyric acid. Revista Brasileira de Fruticultura, v.27, n.1, p.182-184, Apr. 2005. Available from: <http://www.scielo.br/scielo.php?pid=S010029452005000100049\&script $=$ sci_arttext $>$. Accessed: May 06, 2015. doi: 10.1590/S0100-29452005000100049.

BIASI, L.A. Etiolation to clonal plant propagation. Ciência Rural, v.26, n.2, p.309-315, Ago. 1996. Available from: <http:// www.scielo.br/scielo.php?script $=$ sci_arttext\&pid $=$ S0 103 $84781996000200025 \& \operatorname{lng}=\mathrm{pt} \& \mathrm{nrm}=\mathrm{i}$ so \&t $\operatorname{lng}=\mathrm{pt}>$. Accessed: May 06, 2015. doi: 10.1590/S0103-84781996000200025.

BUENO, S.C.S. et al. Cultivo do caquizeiro. In: PIO, R. Cultivo de fruteiras de clima temperado em regiões subtropicais e tropicais. Lavras: UFLA, 2014. Cap. 9, p.250-295.

CELANT, V.M. et al. Cold storage of budsticks and grafting methods of quince cultivars. Ciência Rural, v.40, n.1, p.20-24, Jan./Feb. 2010. Available from: $<$ http://www.scielo.br/scielo.php?script $=$ sci arttext\&pid $=$ S0103-84782009005000223 $>$. Accessed: May 06, 2015. doi: 10.1590/S0103-84782009005000223.

CORSATO, C.E. et al. Carbohydrate content in persimmon tree woody organs in tropical climate. Revista Brasileira de Fruticultura, v.30, n.2, p.414-418, Jun. 2008. Available from: $<$ http://www.scielo.br/scielo.php?script=sci_arttext\&pid
$=\mathrm{S} 0100-29452008000200025>$. Accessed: May 06, 2015. doi: $10.1590 / \mathrm{S} 0100-29452008000200025$.

FERRI, A. et al. Viability and in vitro germination rate of pollen grains of $\boldsymbol{D}$. $\boldsymbol{k a k i}$ Thunb., D. lotus L. and D. virginiana L. in relation to storage time and temperatures. Acta Horticulturae, v.996, n.1, p.97-102, Jan. 2013.

KOCHANOVA, Z . et al. Sodium azide induced morphological and molecular changes in Persimmon (Diospyros Lotus L.). Agriculture, v.58, n.2, p.57-64, Jul. 2012. Available from: $<$ http:// www.degruyter.com/view/j/agri.2012.58.issue-2/v10207-0120007-6/v10207-012-0007-6.xml>. Accessed: May 06, 2015. doi: 10.2478/v10207-012-0007-6.

MACIEL, H.S. et al. Viability of citrus bud collected from greenhouse and kept in refrigerated storage. Revista Brasileira de Fruticultura, v.30, n.1, p.241-245, Mar. 2008. Available from: $<$ http://www.scielo.br/scielo.php?script $=$ sci_arttext\&pid=S010029452008000100044\&lng=pt\&nrm=iso>. Accessed: May 06, 2015. doi: 10.1590/S0100-29452008000100044.

MARTINELI, M. et al. Persimmon cv. 'Mikado': analysis of volatile compounds in astringent and astringency removal. Ciência Rural, v.43, n.8, p.1516-1521, Ago. 2013. Available from: <http://www. scielo.br/scielo.php?pid=S0103-84782013000800028\&script $=$ sci arttext>. Accessed: May 06, 2015. doi: 10.1590/S010384782013000800028 .

PIO, R. et al. Propagation of 'Japonês' quince for cutting and air layering technique in different periods. Ciência e Agrotecnologia, v.31, n.2, p.570-574, Mar./Apr. 2007. Available from: <http:// www.scielo.br/scielo.php?script $=$ sci_arttext\&pid $=$ S 1413 70542007000200043\&lng=pt\&nrm=iso\&tlng=pt $>$. Accessed: May 06, 2015. doi: 10.1590/S1413-70542007000200043.

SEIFERT, K.E. et al. Pear seedling production by double grafting in quince using 'Japonês' as rootstock. Pesquisa Agropecuária Brasileira, v.44, p.1631-1635, Dec. 2009. Available from: $<$ http:// www.scielo.br/pdf/pab/v44n12/v44n12a10.pdf $>$. Accessed: Nov. 14, 2013. doi: 10.1590/S0100-204X2009001200010.

ZANANDREA, I. et al. Tolerance of Sesbania virgata plants to flooding. Australian Journal of Botany, v.57, n.8, p.661-669, Feb. 2009. Available from: <http://www.publish.csiro.au/paper/ BT09144.htm>. Accessed: May 06, 2015. doi: 10.1071/BT09144. 